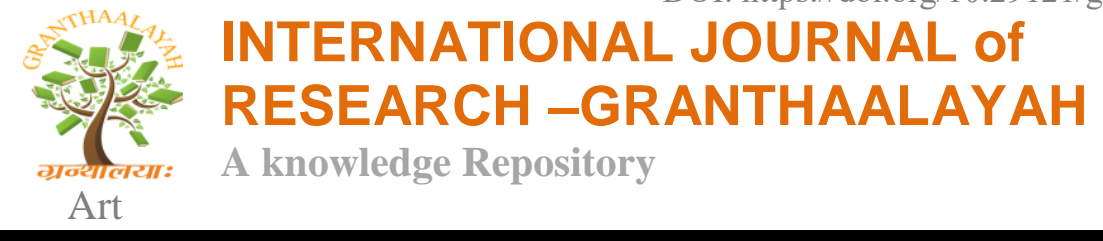

\title{
“COLOR AS FIELD” Weightless \& Floating Free
}

\author{
Vinay Kumar \\ Asst. Professor
}

State University of Performing \& Visual Arts.

State Institute of Fine Arts, Sector-6, Rohtak

"Although the composition and function of colour are two of the most important factors in determining the qualitative content of a painting, the reciprocal relation of colour to colour produces a phenomenon of a more mysterious order. This new phenomenon is psychological. A high sensitivity is necessary in order to expand colour into the sphere of the surreal without losing creative ground. Colour stimulates certain moods in us. It awakens joy or fear in accordance with its configuration. In fact, the whole world, as we experience it visually, comes to us through the mystic realm of colours. Our entire being is nourished by it. This mystic quality of colour should likewise find expression in a work of art". Hans Hofman.

"My canvases are not full because they are full of colours but because colour makes the fullness. The fullness thereof is what I am involved in. it is interesting to me to notice how difficult it is for to take the intense heat and blaze of my colours. If my paintings were empty they could take them with ease". Barnett Newman.

Key Words: Colour Field Paintings, Abstract Expressionism, Action painting, Sublime,

\section{ABSTRACT EXPRESSIONISM}

\section{0s - Late 1950s}

Abstract Expressionism flowered in the 1940s and 50s in New York. It covered a variety of painting styles, but all its practitioners conveyed a strong emotional content, emphasized the sensuousness of paint, and generally worked on large canvases. The term Abstract Expressionism was first used in connection with modern American painters in 1945 by Robert Coates, art critic of The New Yorker, but it had also been applied to the work of Wassily Kandinsky in the 1920s. By the 1950s the term was in common currency, even though some abstract Expressionists, such as Willem de Kooning, did not produce abstract work.

\section{INFLUENCES}

The Surrealists were a major influence on the Abstract Expressionists. Their ideas of unleashing the power of the unconscious and painting automatically were adopted by the Abstract Expressionists - as was biomorphism, a style of painting based on non-geometric shapes and motifs that evoke living things. Most of the Abstract Expressionists - including its two best-known artists, Pollock and Rothko - began painting in a biomorphic style in the 1940s. Abstract Expressionism was also a response to post-war American society. In a conservative, and increasingly homogenized culture, artists felt a need to communicate their innermost feelings and experiences. In doing so, they created the first American art movement to achieve worldwide influence. 


\section{INTERNATIONAL JOURNAL of

\section{TIME LINE}

Abstract Expressionism grew out of Surrealism. Gottlieb's Eyes of Oedipus and Pollock's Eyes in the Heat retain the non-geometric biomorphic imagery favored by the Surrealists. David Smith's sculpture, created from agricultural implements, suggests action suspended. By the mid- 1950s Rothko had established his Color Field style and Borduas was pursuing his "all-over" painting. De Kooning carried Abstract Expressionism into the 1960s.

\section{INTERPRETATIONS}

Abstract Expressionists can broadly be divided into two groups. The Action painters, a term coined by the critic Harold Rosenberg in 1952, included Jackson Pollock, Willem de Kooning, and Franz Kline. Their paintings are full of drama, with the paint applied urgently and passionately. The color Field painters, championed by critic Clement Greenberg, include Mark Rothko, Barnett Newman, and Clyfford Still. Their paintings are quieter and emphasize the emotional force of color.

\section{ACTION PAINTING}

In Action painting, the "act" of painting becomes the content of the work - so the image reflects the raw emotions held by the artist while creating it. Action painters poured, dripped, and spattered paint on to the canvas. Hans Hoffman was among the first to do this, but Pollock took the technique to its logical conclusion - he abandoned the restrictions of brushes and upright easels to create images that he described as "energy and motion made visible". These pictures, full of restlessness and flux, with no one part of the picture more important than another, were said to be "all-over" in style.

Rosenberg summed up Action Painting: "what was to go on canvas was not a picture but an event". Pollock's work, in particular, looked forward to the performance art and happenings of the 1960s. Look at a Pollock and you have a record of his "performance".

\section{COLOUR FIELD PAINTING}

When Action Painting was bold and assertive, Color Field painting was contemplative and carefully constructed. The works consist of large expanses of color, often without strong contrasts of tone or obvious focal points.

Many Colour Field paintings were intended to create transcendental feelings of awe and wonder. Newman said his art was "religious" and concerned with the "sublime". Rothko said his work was about "the basic human emotions - tragedy, ecstasy, doom". The huge size of many of these paintings does seem to overwhelm the viewer, inducing a feeling of isolation in a limitless world. 
If Action painting was the result of a heightened state of consciousness on the part of the painter, Color Field painting was intended to create a heightened state of consciousness on the part of the viewer.

\section{IMPORTANT ARTISTS OF THE PERIOD}

\footnotetext{
- Jackson Pollock

- Willem de Kooning

- Mark Rothko

- Barnett Newman

- Arshile Gorky

- Adolph Gottlieb

- Lee Krasner

- Clyfford Still
}

- Hans Hofmann
- Franz Kline
- Robert Motherwell
- $\quad$ Paul-Emombly
- Jean Paul Riopelle
- Philip Guston
- Ad Reinhardt

\section{JACKSON POLLOCK}

\section{b. CODY, 1912; d. NEW YORK, 1956}

Jackson Pollock was a leading exponent of Action Painting and Abstract Expressionism. Fellow Abstract Expressionist Willem de Kooning said, "he broke the ice for the rest of us".

Pollock began making his drip paintings in 1947. They established his reputation and completely revolutionized the way a painting was supposed to be made. Instead of using an easel, Pollock laid the canvas on the floor. Instead of using brushes, he poured the paint from a can and dripped it from sticks. He also revolutionized the idea of composition. Pollock moved over and sometimes through the canvas with free, dance-like gestures. This created an"all-over" style, where no part of a picture was more significant than any other. The composition had no focal points, and often the center was no more important than the edges. They were pictures, Pollock said, with "no beginning or end".

The drip paintings earned Pollock notoriety as well as acclaim. Dubbed "jack the Dripper" by Time magazine, he was the first American painter to become a star, and he lived up to the reputation, drinking hard and living recklessly. Pollock at work

Pollock made his drip paintings in a barn(farm) at his East Hamton home. The size of the barn allowed him to paint from all four sides. He worked rapidly, stepping up to or on to the canvas again and again, swinging the paint stick with dace-like flourishes and flicks of hand, arm, and body.

\section{TECHNIQUE}

Pollock was influenced by Surrealist automatism - abandoning conscious control of the picture, and instead allowing the unconscious to guide the hand. Pollock stated, "when I am in my painting, I'm not aware of what I am doing." so when painting Autumn Rhythm, Pollock did not have an image in mind. Instead he had an encounter with the canvas. The painting became a record of that encounter - part spontaneous, part considered. When asked if he painted from nature, Pollock replied, "I am nature." 


\section{INTERNATIONAL JOURNAL of RESEARCH -GRANTHAALAYAH \\ A knowledge Repository}

Art

LAYERING OF COLORS: Pollock first applied black paint in complex linear swirls to his unprimed, unstretched canvas. This created a "skeleton" over which he added the other colors. Pollock used enamel house paint because traditional oil paints were not fluid enough.

MARK MAKING: The variety of marks creates whirling visual rhythms and sensations. Elegant, curving lines of dilute black paint contrast with the tick-like marks made with thicker brown and white paint. Colors collide, creating thick textural areas, and spattered paint ensures every area of the canvas is felled with activity. Some marks are the result of careful choreograph movement, others the result of chance; some suggest chaos, others order.

LIMITED PALETTE: On top of the initial application of black, Pollock weaves an intricate web of white, brown, and turquoise-grey lines. The colors evoke the autumn of the painting's title and their energetic application suggests trees in an autumnal gale.

\section{MARK ROTHKO}

\section{b. DVINSK, 1903; d. NEW YORK, 1970.}

The Russian-born painter, Mark Rothko, was a leading Abstract Expressionist whose emotionally resonant use of color led him to be categorized as a color Field painter (an abstract style characterized by its use of large expanses of solid color). In the 1930s, Rothko painted in an Expressionist manner, but in the early 1940s, like many of his fellow Abstract Expressionists, he adopted a Surrealist style, drawing upon the myths of antiquity and using calligraphic, biomorphic imagery. He began to develop the distinctive style for which he is best known - featuring large blocks of color - in the late 1940s. By the end of the 1950s, his work had earned him international acclaim. Despite this, he became increasingly depressed, and eventually took his own life in 1970.

\section{UNTITLED}

\section{5, acrylic and mixed media on canvas, $138 \times 70 \mathrm{~cm}$.}

To create his famous Abstract Expressionist images, Rothko worked on untreated, unprimed canvases. He applied repeated thin layers of pigmentation with light, fast brushstroke, so that underlying layers showed through. The result was a printing of great transparency and luminosity.

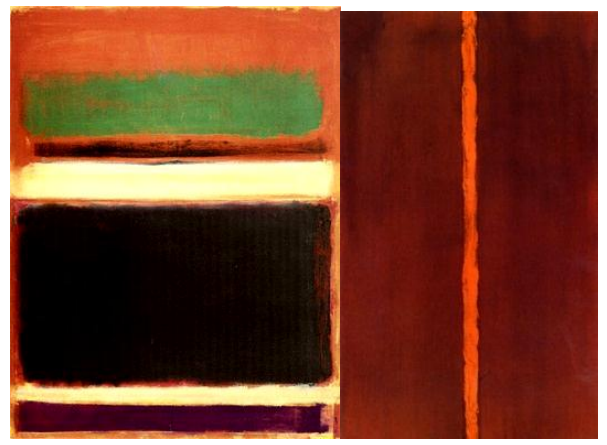

Mark Rothko Barnett Newman 
- The dark sombre work is typical of the paintings Rothko produced in the last two years of his life, lonely, suspicious, and separated from his second wife, he drank, smoked, and took prescribed drugs to excess. His paintings became gloomier and more mysterious, and used browns, greys, and dark blues, or reds and black.

\section{BARNETT NEWMAN}

\section{b. NEW YORK, 1905; d. NEW YORK,1970.}

- After Rothko, Barnett Newman was the pre-eminent color field painter. He became famous for his "zip" paintings, in which he used thin stripes of color against a plain background. He saw the zip as a way of expressing the sublime, and recognized that it was capable of endless explorations. Indeed, he continued to paint zips for two decades - changing their color, width, and the way the paint was applied, so that each painting had a unique personality.

- Unlike his fellow Abstract Expressionists - Pollock, Rothko, and de Kooning Newman was largely ignored by the art world in the 1950s. His reputation was only cemented in 1960s, when Minimalists such as Don Judd admired the way in which he derived his composition from the shape of the canvas. In turn, Newman's late work was influenced by Minimalism, with his zips becoming crisper and less expressive and in the 1960 s he started making equally simplified steel sculptures.

\section{ONEMENT 1}

\section{8, oil on canvas and oil on masking tape, 69x41cm.}

- This painting was Newman's artistic breakthrough - the first time he used his signature mark, the zip. Newman applied the light cadmium red zip on a strip of masking tape creating a thick, irregular band on the smooth field of Indian red.

\section{REFERENCES:}

1. ART "The Definitive Visual Guide", Editorial consultant Andrew Graham-Dixon, DK Publication 2008.

2. New Media in Art by Michael Rush released in 2005, Thames and Hudson.

3. India: Pubic Places, Private Spaces - Contemporary Photography and Video Art, by Gayatri Sinha \& Paul Sternberger, Marg Publication 2007.

4. Collecting Art for Love, Money and More by Ethan Wagner \& Thea Westreich Wagner, published 2013 Phaidon Press Limited.

5. Modern Art by Anarson Thames \& Hudson. 